\title{
Early Burmese Urbanization: Research and Conservation
}

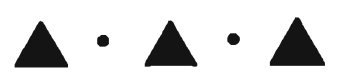

JOHN N. MIKSIC

\section{CULTURAL RESOURCE MANAGEMENT AND ARCHAEOLOGICAL RESEARCH}

ARCHAEOlogical Resources ARE A POTENT source of tourism income. Tourism is the world's largest industry, and its share of the new service-driven world economy is constantly growing. The most popular tourist attractions in the world are heritage assets such as the Parthenon, the Pyramids, the Great Wall of China, Angkor Wat, and Borobudur. Cultural tourism has been the subject of several international conferences held in Southeast Asia in the past few years (Wiendu 1993, 1997, 1999). The consensus of experts from both the tourism industry and heritage conservation is that cultural and heritage tourism, if properly managed, can provide a sustainable source of income, and that proper management can ensure that all parties benefit: cultural and archaeological assets can be preserved, protected, and interpreted with the funds obtained from visitors, and tourists can obtain authentic and educational experiences.

Myanmar is well placed to benefit from this phenomenon. Myanmar's archaeological and architectural treasures have the potential to compete successfully with the other heritage sites just mentioned. But possession of these assets is not enough to ensure success; a proper management plan must be developed and rigorously adhered to. Otherwise heritage assets can rapidly become degraded, and potential income may not materialize. A search for quick profits through poorly planned development is almost certainly doomed to failure. (For examples of the outcome of some poorly planned heritage tourism projects in Southeast Asia, see Miksic $1995 a, 1995 b$. For examples of heritage tourism projects which might be implemented in Myanmar, see Miksic 1999a. Lertrit 2000 has described problems experienced in managing archaeological resources in Thailand and proposes some solutions.)

Several universities and other institutions in Southeast Asia have begun to attempt to address these problems. Tourism studies institutes at Gadjah Mada University in Yogyakarta (central Java) and Universitas Udayana in Denpasar (Bali) are currently directed by men whose main backgrounds lie in archaeological research and teaching (Slamat Pinardi and I Wayan Ardika). The Southeast Asian

John Miksic is an associate professor in the Southeast Asian Studies Programme, National University of Singapore, Singapore.

Asian Perspectives, Vol. 40. No. 1, (C) 2002 by University of Hawai'i Press. 
Ministers of Education Organization's Regional Centre for Archaeology and Fine Arts (SPAFA), located in Bangkok, Thailand, the director of which, Mr. Pisit Charoenwongsa, is also an archaeologist, has sponsored numerous conferences and workshops on subjects related to cultural resource management, including sites and monuments of archaeological importance. In 1995, SPAFA sponsored a conference at the National University of Singapore (SPAFA Workshop on Cultural Resource Management, SW-212) which devoted several days to the discussion of a draft set of recommendations entitled "Unified Cultural Resource Management Guidelines for Southeast Asia. Volume I: Material Culture." That draft in turn referred to the problems identified in the Thailand National Cultural Resource Seminar, held in 1994, which boiled down to the "willingness of the public to profit financially at the expense of cultural resources (businessmen who develop in culturally sensitive areas, farmers who hunt for and excavate antiquities, dealers who traffic in antiquities, and so forth)" (Comer 1994:6).

The draft report included some stringent conditions for the development of archaeological sites for tourism. For instance, the report states:

Original fabric in its original context holds the most and highest quality of information.... More spectacular embellishments to interpretation - sound and light shows, luxurious visitor centers, and so forth-should be considered only insofar as they can be demonstrated to contribute to this interpretive process. (Comer $1994: 11$ )

From an intellectual point of view, this statement is unexceptionable. In order to encourage private developers to adhere to this set of priorities, however, it is necessary to acquire hard data to prove that such preservation is more economically beneficial than more invasive alternatives. The injunction that "the value of such resources cannot be measured by the numbers of visitors" (Comer 1994:12) does not take account of the reality that economic planners control the future, not archaeologists. Without concrete alternative proposals for management of archaeological resources, developers will act on their own basic instincts, which assume that profit is the main measure of achievement, and that profit can be raised by investment in various forms of additions to the "original fabric in its original context." As yet, no alternative system of measurement of the value of cultural resources has gained wide acceptance.

The draft report offered a clue to the means by which an alternative system of measurement might be found. The report posits the proposition that "working strongly in favor of Southeast Asian countries is that cultural properties will be immeasurably more meaningful to tourists seen in the context of their home countries" (Comer 1994:14). This suggests that some way of evaluating "meaningfulness" might conceivably be developed. Economic planners understand figures, and methods to gather them (visitor surveys) do exist. Unfortunately, the converse situation envisioned by the report mirrors the present reality: "Unless the value of original fabric and original context are widely appreciated, cultural properties will be destroyed by development, structures and landscapes will be damaged by inappropriate treatments, and collectors will continue to finance the looting of archaeological sites" (Comer 1994 : 12-13).

Two key components of an endeavor to create a proper long-term cultural resource management plan are research and interpretation. The cultural resource to be developed must be properly understood before it can be marketed. This need 
for understanding justifies a considerable investment in research before any decisions are made regarding what the resource in truth consists of, and how the resource is to be interpreted to the public. The term "interpretation" in cultural resource management can be said to be synonymous with "marketing" in economic parlance. A marketing scheme, in order to generate sustainable income, must strike a proper balance between finding examples in the resource of well-known general elements in order to place the resource in a familiar context, and the effort to identify unique elements which make any particular destination an attraction that cannot be duplicated elsewhere and therefore constitutes a kind of monopoly. Interpretation is thus the basis of any effective campaign to market heritage assets. Interpretation involves making information available and interesting to visitors before, during, and after their visits.

One of Myanmar's principal cultural assets is its ancient cities. From Sri Ksetra to Mandalay, and many points in between, Myanmar can be seen as a true heartland of cities. (For the major urban sites of Myanmar, see Table 1.) Archaeological research may eventually show that this term, popularized by $\mathrm{R}$. $\mathrm{McC}$. Adams in his studies of the cities of Mesopotamia (Adams 1981), is equally applicable to Myanmar. The exploration of ancient cities and their civilizations is one of the most potentially productive and beneficial types of heritage tourism. Cities are large sites, with many facets that can be developed. They can therefore attract many types of visitors, and hold their attention for long periods of time, thus enhancing the economic benefits to be reaped by the host country. Tourists attracted by heritage tourism possess desirable characteristics: they tend to be well educated and culturally sensitive.

How can Myanmar maximize the benefits to be derived from these assets? As stated above, research and interpretation are the key components of a long-term strategy for sustainable development. The principle thrust of this article consists of observations on the most ancient cities of Myanmar, and the types of research projects already conducted elsewhere in Southeast Asia that could lead to the development of a data base, which could then be utilized by those in charge of devising a marketing/interpretation campaign for these resources. Archaeologists engaged in the field of "public archaeology" over the past 25 years have been increasingly influential in convincing other members of the profession that the communication of the results of their research to the public is essential to the survival of this field of study.

Table i. Ancient Urban Sites of Myanmar

\begin{tabular}{lll}
\hline Site & \multicolumn{1}{c}{ APproximate Dates } & \multicolumn{1}{c}{ Literature } \\
\hline Beikthano & 1st-5th centuries A.D. & Aung Thaw 1972:6 \\
Halin & 2nd-6th centuries A.D. & Aung Thaw 1972:15 \\
Sri Ksetra & 5th-9th centuries A.D. & Aung Thaw 1972:16 \\
Pagan & 9th-14th centuries A.D. & Aung Thwin 1985, pers. comm. \\
Tagaung & 9th-12th centuries A.D. & Aung Thaw 1972:103 \\
Inwa & 14th-19th centuries A.D. & Aung Thaw 1972:125 \\
Bago & 14th century-present & Aung Thaw 1972:104 \\
Mrauk-U & 15th-16th centuries & Aung Thaw 1972:119 \\
\hline
\end{tabular}




\section{Cautionary Tales}

Many disastrous projects aimed at the development of cultural resources for tourism have been implemented in Southeast Asia which could have been constructive had archaeologists made known their ability to contribute to the sustainable development of the resources that lie at the center of their research. Lertrit (2000:160-161) documents the opportunities for data gathering and interpretation that have been neglected at Chiang Saen. As a contribution to the discussion of this subject, this article presents suggestions for a marketing strategy which might be considered for implementation in the case of Myanmar's ancient cities. It is hoped that in this way a contribution can be made to the long-term development of Southeast Asian archaeology, and to recognition and preservation of positive aspects of the previous two millennia of urban growth, some of which are unique to this region.

According to one recent source, "During 1996-1997 fiscal year, the Myanmar Archaeological Department was ordered to repair 120 monuments and excavate 175 mounds around Pagan. That was an astonishing news [sic] because the Pagan branch of archaeology office has only one or two trained men to supervise the whole work of nearly 300 sites ..." (Frasch 1998:37). The reason for this sudden burst of activity is that

the present Burmese government intends to place archaeology in the service of tourism which is supposedly more attracted by the spectacular than the authentic: the resources generously allocated to the mediocre reconstruction of the Mandalay palace and to that (completely hypothetical) of the Pegu palace, are far out of proportion to the sums devoted to research on the necessary care of ancient monuments. (Pichard and Robinne 1998:18)

The famous Myanmar historian and archaeologist Than Tun underlines the fact that at Pagan the government

is engaged in a campaign of dismantling and hasty reconstructions, on bases which are uncertain both physically and scientifically. The order given to the Archaeology Department to reconstruct the upper parts of the main monuments is dangerous because it imposes an added burden on the insufficiently strengthened walls, and because it implies, in every case where the upper portions have disappeared, a completely hypothetical restoration without any architectural evidence. (Pichard and Robinne 1998:22).

Despite the richness of the archaeological and historical record, very little effort has been made to exploit the potential of ancient Myanmar to contribute to the understanding of ancient cultural development, whether on local, regional, or global scales. One of the major areas in which Myanmar data should be able to make a significant contribution to mankind's understanding of the development of civilization consists of the study of early urbanization. Although evidence of pre-European urbanization at several sites in Myanmar has been known for decades, the pattern of life in those early urban centers is still indistinct. Another most interesting and urgent subject for further study concerns the nature and functions of the Myanmar urban sites: were they largely ceremonial? Were they built for defensive purposes? To what extent were they commercially oriented? How did responsibility for urban development shift over time among these and other stimuli? 


\section{Formal vs. Functional Definitions}

The principle dichotomy in ancient cities seems to revolve around the two poles of the orthogenetic city (in which the main activities were bureaucratic and religious) and the heterogenetic city (in which economic activities were significant factors). Paul Wheatley (1975) formulated his model of Southeast Asian urban genesis in this manner:

By the beginning of the Christian era, Indian merchants had worked their way through the sea-lanes of Southeast Asia and familiarized the tribesmen of certain strategically situated territories with a range of material products, and probably also with some of the less tangible benefits, of Indian civilization. (Wheatley $1975: 235$ )

According to Wheatley's perspective, Southeast Asian urbanization came about as the result of "the total transformation of economies that was engendered by the extension of South Asian commercial entrepreneurship into the southeastern angle of the continent" (Wheatley $1975: 257$ ). Wheatley later expanded on his ideas at length (1983), but the fundamental implication remained the same: that the first urban lifestyles in Southeast Asia evolved as a result of external influence.

One problem in trying to test Wheatley's hypothesis is that he offers no discernible archaeological correlates which his urban centers should create. Instead he only provides such generalities as the statements that urbanized society is "a generalized level of sociocultural integration" which is marked by buildings, but also institutions, patterns of land use, division of labor, "a way of life," and interdependence characterized by expansion of "a sphere of compliance and control" (Wheatley 1983:20). He characterizes the city as "a focus of innovation." It is difficult to translate these concepts into physical traits which can be detected by archaeological means and used in empirical research to distinguish between urban and nonurban settlement forms. (For further critiques of Wheatley, see Christie 1995; Miksic 1991.)

Wheatley is not an exception in his failure to provide suggestions of concrete signs of urban sites for which archaeologists could search. Wheatley might be forgiven for this failing, since he is not an archaeologist but a geographer. Archaeologists, however, have been guilty of the same sin, and they have no such excuse. For example, Manzanilla (1997:5) formulated the clearly circular definition of an "urban society" as one possessing occupational specialization, "institutions that coordinate economic processes," and "specialists in decision-making that live in an urban center." Other deficiencies common to most attempts at definitions of urban sites include a lack of concrete characteristics which can be used to classify archaeological sites as urban or nonurban; lack of allowance for variability in the states of the various attributes used to characterize the city or urban society, and thus inability to detect or explain it; and indifference to the possibility that different societies can arrive at the same settlement pattern through different evolutionary paths. When societies achieve the same end state after passing through a sequence of multi-attribute states different from that of classical examples such as Mesopotamia, these evolutionary pathways are usually perceived as "deviant" and the result of foreign influence. The idea of convergent evolution, of analogy rather than homology as the principal mode of urban evolution, is ignored.

As a step toward ameliorating the problem of vague and overlapping definitions of the "city," one option is to distinguish between two categories: "func- 
tional" and "formal." Formal definitions, the simpler of the two options, depend on observation of physical characteristics such as site size or population. Such definitions are easiest to implement, because they are very specific. This quality, very useful for the archaeologist, however, also constitutes a weakness: how do we defend the selective use of some criteria and not others? Ideally we would have enough information to show that these criteria are associated with one another in a frequent manner, yielding a high correlation coefficient, thus supporting the inference that they are not randomly distributed, but are rather connected by some causal mechanism. Most investigators of urbanization have chosen to avoid this problem by employing functional definitions, based not on physical criteria, but on the nature of activities and institutions believed to have existed in a particular time and place. These different definitions of cities produce quite different results when applied to the available data. The contrast between these two definitions can be clearly seen by comparing a map of fourteenth-century urban sites in Southeast Asia reflecting a functional definition (Wheatley 1983:426, fig. 22) with that created for the sixteenth century using a more formal definition (Reid $1993: 76$, map 5).

Michael Coe (1961) distinguished two types of civilizations which he termed unilateral and organic (terminology borrowed from the famous sociologist Emile Durkheim). He compared the Maya to the Khmer and inferred that societies characterized by mechanical solidarity would arise in "areas which are environmentally undifferentiated [and] will tend to lack an early growth of urbanism" (Coe 1961:67). Later, ecologically oriented authors would say that the finegrained resource distribution typical of some tropical environments lessens the incentive to humans to work out elaborate market-based exchange systems. Instead the economy tends to follow a redistributive model wherein the main decisions about allocation of resources are made by the central administration (kingdom, religious center).

Coe's formulation is preferable to that of Wheatley in that it assigns responsibility for differences in nature and timing of the development of socio-economic complexity not to different levels of human capability (which his model implicitly implies), but to environmental variables. He argues that one specific type of interaction between settlement and environment can be accounted for by different levels of ecological diversity.

Nevertheless, Coe's argument also has its faults. He discusses "the tropics" as a single environmental type. This obscures the great degree of diversity that is known to exist within that grand geographical unit. Because of this overgeneralization, he cannot account for the obvious differences observable between various parts of the tropics within one region, such as Southeast Asia, where complex settlement patterns emerged at different times and took different physical forms.

It is not only plausible, but also suggested by the data which has been amassed up to now, that in Southeast Asia the economic and social formations associated with urbanization in other parts of the world appeared at a date not too dissimilar from the timing observed elsewhere, but sites with attributes which would identify them as cities did not. What is the explanation for this?

The earliest dates for regional trading systems in prehistoric Southeast Asia have been largely inferred from burial sites containing imported items, not from 
large complex residential areas. It is possible that large nucleated settlements existed near these cemeteries but have avoided discovery, or that they did not exist until several centuries later.

Another difficulty with most evolutionary schemes is that they assume a unilinear trajectory. In some Southeast Asian cases, of which Myanmar provides at least one example, it seems that there has been a kind of oscillation between traits characteristic of different kinds of cities even at the same site. This complexity of development cannot be accounted for by any extant theory of Southeast Asian urbanization.

\section{TWO TYPES OF CITIES}

In 1954, Redfield and Singer suggested that we should distinguish two types of cities: one type, called orthogenetic, which is associated with stability and ritualized behavior; and a second type, termed heterogenetic, associated with change and entrepreneurial behavior. Both types of city can coexist in the same region (for a recent discussion of the application of this concept to five sites of pre-European urbanization in Indonesia and Singapore, see Miksic 2000; for a similar characterization of early European urbanization, see Fox 1971). The discussion of two types of city as employed in this article are not meant as mutually exclusive categories; in reality, specific archaeological sites will probably exhibit aspects of both forms of behavior (religious and economic). Any typology of archaeological sites based on settlement patterns and site functions would have to take many more variables into account. The postulation of two types of sites here is merely intended as a means of simplifying the discussion in order to get at critical variables of one particular dimension. Many other dimensions should be taken into account in order to arrive at a viable typology able to reflect reality accurately enough to be amenable to manipulation in the context of solving problems of evolutionary processes, interaction between sites, etc. For this and other reasons, it is impossible to enter into a full discussion of the alternative definitions of "cities" and "urbanism" in this article. Once again, the reader is referred to Miksic (2000) for more discussion. See also Miksic (1989) for explication of the possibility that the English word "city" is itself a culturally biased concept and therefore cannot be used as an analytic term when dealing with non-Western societies. Miksic (1989) discusses some of the words and cultural categories which the people of one part of Southeast Asia (Sumatra) use to think and talk about comparable units of settlement and human association. A complete study of historical and ethnographic concepts of and terms for settlement and spatial units in Southeast Asia would be a tremendous feat of comparative research; as yet nobody has accomplished this task.

\section{Orthogenetic Cities}

We can postulate archaeological attributes that would enable us to differentiate sites with a mainly orthogenetic character from those sites that functioned primarily in a heterogenetic manner. Orthogenetic cities should be marked by monumental architecture, either of a political or religious nature. They would therefore be easy to find, and would attract a great deal of attention both from archaeologists and others because of the permanent art works they created. Eco- 
nomic activities in orthogenetically organized societies would be redistributive, wherein authorities control most production through taxation and tribute and distribute it as largesse and payment in kind. Such cities would normally be found in areas with relatively undifferentiated environments (to borrow Coe's term) where a surplus of staple crops, such as rice, can be produced efficiently, collected and transported to centralized storage facilities, and redistributed according to a centrally planned system. Such sites would not be associated with the development of coinage, since markets play little role in everyday life.

Evidence for manufacturing activities is occasionally found at the sites of orthogenetic cities. These manufacturing centers are, however, often found outside the core of the monumental area, scattered around its fringes, or located at some distance away (for examples, see Wheatley 1971). Due to the administered nature of the organization that governs procurement of raw material, compensation of work force, and distribution of the finished products, each manufacturing workshop in an orthogenetic society tends to specialize in one particular type of product. Orthogenetic sites normally lack one significant type of artifactual assemblage: habitation remains left by a dense population. The monuments were built by workers imported from the agricultural areas outside the ceremonial centers, most of whom were only seasonally employed at their tasks. The pyramids of Egypt, for example, were built in this way. The only permanent residents in orthogenetic cities were nobles, bureaucrats with civil, religious, and military duties, and their support staff.

Elites throughout history have sought exotic items through long-distance trade as status symbols. The leaders of orthogenetic cities provide some of the most extreme examples of this phenomenon, since their status is based upon ritual display and ceremonial use of rare commodities such as incense. Most orthogenetic cities, therefore, yield evidence of long-distance exchange. Institutionally, such exchanges were traditionally organized not by market-place trading but through customary exchanges of items through diplomatic channels as part of a network of international relations.

One well-known example of a site with a large preponderance of traits characteristic of the orthogenetic city on the basis of presently available evidence is Angkor in Cambodia. Angkor is situated in a highly productive environment. The remains on the site consist primarily of religious monuments. No extensive areas of nonelite habitation have yet been found there. Coinage was used in preAngkor Cambodia (Wicks 1992) but after Angkor was founded, conventionally dated in A.D. 802, coinage disappears from Cambodian archaeology. Thereafter inscriptions show that most economic activity was regulated by the central government. Evidence for long-distance commerce suggests that it was mainly conducted in the context of the procurement of commodities for the royal ceremonies and temples. The development of an orthogenetic city at Angkor marks an important break with the previous tradition of the Oc-èo culture in the lower Mekong, which was a major heterogenetic site.

As Redfield and Singer noted, orthogenetic and heterogenetic cities may coexist in the same area. The presence of orthogenetic sites does not preclude the presence of heterogenetic sites. Furthermore, it should be noted that as information increases, it will be possible to arrange sites along a continuum according to the degree to which they more closely resemble the heterogenetic or orthoge- 
netic ends of the spectrum. Orthogenetic and heterogenetic are after all polar extremes, not mutually exclusive categories. Numismatic data suggests that as in the lower Mekong, social evolution may actually have manifested itself in a gradual (or perhaps even sudden) transition from a position closer to the heterogenetic end of the scale to another position nearer to the orthogenetic end. Meanwhile the insular area of Southeast Asia may have been evolving in the opposite direction. There is thus no unilinear nor inevitable evolutionary implication of this dimension of variation, nor any preclusion of a high degree of variability even within the same site from one period to another.

\section{Heterogenetic cities}

Heterogenetic cities, in contrast to orthogenetic cities, produce few monuments. The main generator of heterogenetic sites is a dense population engaged in a wide range of economic activities, in which market-based economies dominate. Evidence of this range of activities, and the existence of market-based exchange, is frequently associated with abstract media of exchange, i.e., money or coins, and evidence for production of a wide range of materials from imported raw materials. Artifact assemblages found at such sites usually include large quantities of unimpressive utilitarian pottery and industrial refuse, as a result of which heterogenetic cities have attracted less attention from archaeologists and other observers.

Recent studies by influential scholars (for example, R. L. Wicks [1992] and A. Reid [1988, 1993]) have concluded that a major discontinuity occurred in the evolution of the economic system of Southeast Asia around A.D. 1400; according to this interpretation, during the period 1400-1450 a new economic pattern evolved, in which several Southeast Asian societies evolved from those largely ruled by redistributive, nonmarket economies, into others in which a more fluid, exchange-based system evolved. In terms of settlement types, this would correspond to a shift from orthogenetic to heterogenetic cities. Wicks and Reid also concur in their inference that Islamization constituted a causal factor in the transition to new economic structures. One might conjecture that the spread of Theravada Buddhism could have been responsible for a similar transition on mainland Southeast Asia.

Research at archaeological sites in Indonesia, which date from the preceding centuries (from A.D. 1100 to 1400), paints a different picture from that which Wicks and Reid assume to be true. The fifteenth century was not representative of a discontinuity with the past. The new evidence suggests instead that a gradual transition to a new mode of economic interaction took place both within certain parts of Indonesia and between Indonesians and their long-distance trading partners. While the introduction of Islam affected some of the external form of the new economic institutions, such as a shift to Islamic-type coinage, economic transitions were already taking place prior to Islamization (Miksic 1998).

\section{INSULAR SOUTHEAST ASIA}

The oldest archaeological evidence of trade between South Asia and Indonesia appears in the form of Romano-Indian rouletted pottery, examples of which have been found in west Java (Walker and Santoso S. 1977) and Bali (I Wayan Ardika 
and Bellwood 1991). Two Chinese envoys, Kang Tai and Zhu Ying, in the early third century A.D., visited Funan and the Kra Isthmus on the Malay Peninsula in order to compile a report on Southeast Asian maritime commerce. This report, entitled Nan chou $i$ wu chih, mentions a place called Ko-ying, which traded with the Malay Peninsula as well as India, from whence it imported horses; its products included pearls, gold, jade, and areca nuts. It did not trade with China, however (Wolters 1967:49-61). The information recorded about Ko-ying suggests that it was probably in western Java (Wolters 1967:227 n. 53). A mid-sixth-century Chinese manuscript, the Lo yang chia lan chi, describes Ko-ying as the most powerful country in the southern barbarian lands (Wolters 1967, appendix A).

By the end of the seventh century, southeast Sumatra had become the center of a kingdom known as Srivijaya, which played a major role in shipping between South Asia and China; a Chinese monk, Yijing, in 671 sailed all the way from Guangzhou to India in ships belonging to Srivijaya's ruler. Srivijaya continued to monopolize maritime trade passing through the Straits of Melaka for the next four centuries.

Archaeologists, however, have encountered difficulty in correlating Chinese and Arab descriptions of Srivijaya's wealth with material remains (Bronson and Wisseman 1976). Concentrated archaeological research has yielded some notable results, but much of Srivijaya's original material culture may be permanently lost due to the consequences of such factors as use of mostly perishable materials and life on rafts or stilt houses built above flowing water (Manguin 1987).

Archaeological research at the site of Kota Cina ("Chinese Stockade") in northeast Sumatra unexpectedly yielded abundant evidence of much economic activity, including imports from China, between the late eleventh and late thirteenth centuries (Edwards McKinnon 1984; Miksic 1979). Chinese copper coins were casually strewn over much of the site, an indication of their ubiquity and common usage. Research at another important site of the early second millennium A.D., Barus, on Sumatra's west coast, has begun to bear fruit (Guillot 1998). Further pursuit of such clues is likely to add significantly to the picture of early heterogenetic settlement in this region. Much additional data are needed before firm conclusions can be drawn, but at least there are signs that research has begun to address some of the significant questions regarding early sites with much evidence of economic activity and few monuments, in other words, heterogenetic sites.

\section{MAINLAND SOUTHEAST ASIA}

Sites with earthen embankments and outer "moats" or depressions formed by the removal of earth for ramparts discovered in northeast Thailand (Kijngam et al. 1980; Moore 1988) have occasioned much speculation. The inception of the construction of such sites seems to date to the second half of the first millennium B.C. Their functions are still unclear, although many suspect that they represent some type of early urban settlement pattern. They do not, however, seem to have led to any lasting traditions of urbanization in that area.

The oldest site which possesses numerous characteristics of the heterogenetic city in Southeast Asia is that of Oc-èo, in the southern Mekong delta. Oc-èo culture flourished for four hundred years (from the early third to early seventh centuries A.D.). The site yielded abundant evidence of a dense population living 
within a patterned settlement enclosed by several rectangular ramparts and ditches. It engaged in a wide range of specialized occupations producing finished products from imported materials. Oc-èo entered into commercial exchanges with China and India, as well as around the South China Sea. Unfortunately most of what we know of this site (Malleret 1959-63) was gleaned from unsystematic excavations. In the 1990s Vietnamese and foreign scholars were finally able to conduct some controlled excavations at the type site and other related locations. Publication of the results of those projects holds the potential to contribute greatly to progress in the subject under discussion here.

A related site where research has only recently begun (Stark et al. 1999) lies further up the Mekong River at the Angkor Borei site. Angkor Borei may have been the political center of the polity known from Chinese sources as Funan, which may have included Oc-èo in its domain (Vickery 1998:45). Inscriptions and architectural remains indicate that Angkor Borei had at least some significant monuments. This does not however automatically demonstrate that Angkor Borei had no economic significance. It cannot be assumed that the conceptual dichotomy between heterogenetic and orthogenetic corresponded to a literal division of all Southeast Asian ancient urban sites. It is possible that some sites may in fact contain evidence that monuments and significant market activity coexisted in approximately equal measure in some sites in early Southeast Asia; in this case, Southeast Asia would present an interesting contrast with early medieval Europe as described by Fox (1971), where societies could be clearly distinguished according to whether they lay near one end of the spectrum or the other. As yet, however, the existence of such sites where both heterogenetic and orthogenetic factors were significant in ancient Southeast Asia has not been demonstrated. ${ }^{1}$

The area of central and northeastern Thailand is associated with the name Dvaravati. Knowledge of the nature of political and cultural organization in this region during the late first millennium A.D. is still exiguous, but some important preliminary information has been compiled and analyzed (Brown 1996; Mudar 1999; Vallibhotama 1984). We are unable at this time to make any judgment regarding the question of whether settlements of this region and time period approximated more nearly the heterogenetic or orthogenetic model.

\section{MYANMAR}

The site of Beikthano in central Myanmar has the distinction of having been the object of one of the first intensive urban archaeological investigations to have been conducted and published in some detail by a Southeast Asian archaeologist (Aung Thaw 1968, 1972). Major renovation work has been carried out on the site, consisting of excavation and dismantling of brick foundations of brick structures and resetting them in cement. Numerous other such projects have been carried out in most countries of Southeast Asia in order to increase touristic potential, with a methodology based on the assumption that physical structures ("monuments") have the greatest power to attract visitors, and conversely, that information regarding the economy and society of the site is not useful or important to collect. As a result, much potential information on the architectural and artifactual assemblages has been destroyed. Beikthano's remote location makes it likely that few tourists will in fact visit the site, and those who do may well be disappointed 
by the lack of interpretation to be found there, and the obvious alteration of the original ruins.

Beikthano is only one of a number of Myanmar sites in which the exiguous available data must be examined in order that the nature of the earliest Southeast Asian urbanization can be understood.

At this moment, we have no information on which to base a determination of which cities were heterogenetic and which were orthogenetic. Beikthano, Halin, Thaton, and Sri Ksetra, from the first millennium A.D., and Pagan, from the early second millennium A.D., to name five of the most famous ancient cities of Myanmar, would seem to be candidates for orthogenetic status, but it is impossible to confirm this diagnosis as no systematic effort to map the distribution, density, and limits of habitation remains in Myanmar sites has ever been conducted, to the best of this author's knowledge.

\section{Numismatics, Economics, and Urbanization}

Silver coins of many designs and denominations have been found in Myanmar. The oldest inscribed Southeast Asian coinage was issued in Arakan (the western coastal area of Myanmar) between A.D. 454 and 476. The main motifs were the conch and srivatsa, which were probably based on traditions already extant in Pyu coinage, but which cannot yet be securely dated (Wicks 1992:86). The Bago area is also associated by anecdotal accounts with numerous types of conch/srivatsa coins. Examples of this type of coin have been found distributed over a long string of sites from Bengal on the west through Syriam and Sri Ksetra, in Myanmar, to U-Thong, central Thailand, and Tavoy, south Thailand to Oc-èo (Wicks 1992: 109), suggesting an extensive sphere of interaction.

The most widespread of all ancient Southeast Asian coinage, decorated with the "rising sun" motif, seems to have originated from the Pyu region of central and upper Myanmar; examples are reported from Sri Ksetra, Halin, and Beikthano, as well as other sites. Related forms found in Thailand, Cambodia, and Oc-èo, have been ascribed to Dvaravati and Funan. The largest single hoard of these coins has been found in Nakhon Si Thammarat, south Thailand. The coins were made in several denominations, indications of sophisticated monetary sense and a need for a diversified medium of exchange among the populations using them.

When the great site of Pagan was founded in the ninth century, we are confronted with the fact that archaeologists have failed to discover any coinage associated with this site or any other from the Pagan period. As an enormous ceremonial center was constructed over the next two centuries, archaeological evidence for the use of coinage is absent. This negative evidence suggests that Pagan shared some traits with Angkor, with which it was contemporary. Pagan may have exemplified a very orthogenetic type of development. Inscriptions from the time of Kyanzittha (1084-1111) described him as being rich, but his wealth was expressed in terms of "many storehouses" rather than money.

There is, however, one eleventh-century inscription which says his wealth was 80 koti (Wicks 1992). What precisely this quantity expressed, we do not know. It may perhaps have been a weight of silver, and if so, one can speculate that this metal still had an exchange function in the early Pagan period. The differences 
between the inscriptions may well be due to conventions related to different genres of edicts; the more poetic style may have explicitly eschewed quantitative terminology, while a more bureaucratic style may have reflected the reality of everyday life more closely.

Inscriptions from Pagan show that tribute offered the king was given in terms of commodities rather than coins. Early Pagan may have been more orthogenetic than the earlier cities of Myanmar. By 1196, however, the Burmese used silver and gold as measures of value and media of exchange. Though no coins of this period have been found, it is possible that objects in some other form such as bars were used as a medium of exchange (Wicks 1992:132). By the thirteenth century various occupations such as silversmiths, potters, musicians, statue makers, painters, wood carvers, and even clothes washers were paid wages. Nevertheless, Wicks (1992:147) suspected that "at least some commercial activities [such as salt making] were administered by the state."

There is no substitute for quantitative data, of the type which can only be procured through thorough archaeological survey according to standardized procedures. Subjective impressions of Pagan obtained by walking over the ground suggests that many areas in fact may have been densely inhabited, to judge from the dense scatters of ceramic sherds littering the ground. A similar problem confronted archaeologists working in Indonesia ten years ago; a description of the technique employed to grapple with the same situation there, and the results obtained, suggest that a similar project in Myanmar would yield valuable new discoveries.

\section{A MODEL FOR URBAN ARCHAEOLOGICAL SURVEY}

The Javanese court poem Desawarnana (commonly known as the Nagarakrtagama), written in 1365, lists many dependencies of the kingdom of Majapahit. A sixteenth-century semihistorical Javanese source tells a story of an oath taken by Majapahit's prime minister around 1330 to subjugate a list of countries of insular Southeast Asia. Various sources support the inference that Majapahit did exert some kind of influence over local kingdoms from Sumatra to the Moluccas. In the fifteenth century the kingdom was frequently rent by internal disputes. By A.D. 1500 other claimants to the position of primus inter pares among the polities of Java had surpassed Majapahit, and the kingdom eventually vanished around 1527 .

No comprehensive description of the capital survives, although several sources discuss the royal palace compound and associated religious complexes. Majapahit's capital during most of the kingdom's existence was located in the vicinity of the modern village of Trowulan. Numerous brick structures datable to the fourteenth and fifteenth centuries were excavated and restored by Indonesian archaeological authorities in the 1970s and 1980s, but overall survey of the site lay in the future. Only standing architectural remains had been mapped. Information available at that time suggested that "the later, fourteenth century site of the Majapahit capital of East Java, although evidently large, shows few urban characteristics.... It is unlikely ... that [the as-yet-to-be-discovered sites of early Javanese palacecapitals] will look any more like the remains of true cities than does Majapahit" (Christie 1992:171). This statement reflects the fact that in the year 2001, no sites with characteristics correlated with heterogenetic cities predating the fourteenth century have yet been discovered in Java, with the exception of Trowulan. 
The realization that Trowulan was not an orthogenetic site only arose as the result of a three-year archaeological survey (Miksic 1994). ${ }^{2}$ The project was not originally intended to test the hypothesis that the site was heterogenetic. The survey's objectives were to attempt to define the site's boundaries, and to record the destruction then as now being occasioned by the local population who are steadily excavating the ruins of brick buildings in order to grind them into powder that is then either mixed with cement to make "red cement" (which is believed to make buildings stronger) or with clay to make new brick. Trowulan's location in the east Javanese hinterland, without even convenient access to riverine transport, and the lack of references to trade in historical texts, led to the assumption that Trowulan was an orthogenetic site.

The survey's methodology consisted of surveying transects on foot by about 40 field workers consisting of junior members of the Archaeological Service and upper-level university students, mostly Indonesian but with a few Singaporean participants. The research design was relatively simple, but such randomized sampling surveys have rarely been conducted in Southeast Asia, nor have they usually covered such extensive areas. Another feature of the Trowulan survey was that the distribution of artifacts was correlated with contemporary land use, enabling researchers to calculate the impact of modern activities on the probability that surface survey would yield reliable data.

Results of the survey contradicted the expectation that few remains of dense settlement and economic activity would be found. Instead the results of the survey indicated that Trowulan had been a densely inhabited site engaged in a wide range of productive activities and importing large amounts of foreign ceramics for a period of at least two centuries (A.D. 1300 to 1500).

In a recent study of heterogenetic cities in Indonesia and Singapore (Miksic 2000), four sites of the twelfth to sixteenth centuries were found to have had relatively small areas, and were possibly provided with some sort of defensive features, although they may not have been completely enclosed by them. Trowulan does not seem to have had such a defensive structure, and it includes some hydraulic features that could not have been settlement areas. These water-control features may have served symbolic as well as sanitary purposes (Miksic 1999b) to compensate for the lack of a large river or other natural water source nearby.

Trowulan may have been characterized by a discontinuous distribution of densely inhabited nonagrarian settlement quarters, known as kuwu in Javanese. This type of settlement may have been characteristic of early Myanmar as well, where the areas covered by sites such as Beikthano (9 sq $\mathrm{km})$, Halin $(5 \mathrm{sq} \mathrm{km})$, and Sri Ksetra (18 sq $\mathrm{km}$ ) are defined by surrounding walls. The areas enclosed by these walls (or earthen embankments) may also have been subdivided into areas of highly varying population density, each of which may have had its own boundary. In Trowulan and the sixteenth-century site of Banten Lama, texts and modern place-names indicate that the residential quarters within the outer walls were each controlled by a nobleman, and had specialized functions such as pottery making, bronze casting, animal butchering, and gold working, or were inhabited by bureaucrats from certain departments.

One plausible interpretation for the data from Trowulan is that the site was originally established as a ceremonial center. There is evidence in the form of a ninth-century inscribed copper plate that some type of royally sponsored reli- 
gious foundation existed at that time. In the fourteenth century, the ceremonial center or orthogenetic city may have begun to evolve in the direction of a heterogenetic site. This would provide an example of the opposite tendency from that observed in Myanmar during the transition from the Pyu to the early Pagan period.

\section{CONCLUSION}

Authors such as Wheatley (1983) and K. R. Hall (1985) have concluded that Southeast Asian urbanization was imposed from without. Although this argument can be partially refuted on logical grounds (Miksic 1991), it would be more satisfactory to correlate sites of heterogenetic cities with the presence or absence of foreigners. This we cannot do. We can, however, note an argument at a higher level of abstraction. Trade between South Asia and Southeast Asia began approximately 2,000 years ago (Glover 1989; Higham 1989). Some heterogenetic cities may have evolved on the Southeast Asian mainland beginning in the third century A.D., but no evidence of such early cities has yet emerged in the insular regions. There is, however, a correlation between the appearance of heterogenetic cities in the insular realms and the beginning of Chinese residence overseas, which can be documented in Chinese archival sources as having begun around A.D. 1200. Kota Cina is in fact the oldest heterogenetic city which can be unequivocally demonstrated using archaeological data to have existed in Indonesia. It seems likely that this correlation is causal rather than fortuitous. Early heterogenetic cites in Sumatra and Singapore may therefore have formed due to the presence of Chinese immigrants.

It seems unlikely that the same conclusion applies to early Myanmar cities. Research at such sites as Beikthano, Sri Ksetra, and Halin does not indicate any major foreign component in the population. These cities seem to have appeared as much as a thousand years before comparable developments took place in insular Southeast Asia. The process of urbanization on mainland Southeast Asia probably followed a very different pathway from the areas around the Straits of Melaka. A parallel with early Myanmar cities may be found in fourteenth-century east Java, where a heterogenetic city may have formed without a large foreign quarter. Interestingly, the direction of evolution seems to have been different in the two regions of Southeast Asia: from heterogenetic to orthogenetic in Myanmar, from orthogenetic to heterogenetic in Java.

Were the early cities of Myanmar closer to the orthogenetic or heterogenetic pole of this dimension of variation, i.e., was religion most responsible for the existence and form of the site, or did economic activity play the role of single most important factor shaping the architecture and institutions of the place? This question cannot yet be answered. A program of archaeological survey similar to that which was implemented at Trowulan could go a long way toward resolving this problem.

The answer to this question has important implications for the future of heritage resource management in Myanmar. If early Myanmar cities were heterogenetic, with a much wider range of activities than religion and ritual, then this 
would affect the basic mode of interpretation (marketing strategy) for the main sites concerned. If it could be proved that a complicated lifestyle involving a wide range of occupations had arisen in Myanmar between 1,500 and 2,000 years ago, then this lifestyle could be recreated utilizing various display techniques. Much detailed archaeological research would be necessary; the survey would be merely a first step. The present method of reconstruction of Myanmar's monumental complexes seems to be based on the assumption that the monuments alone tell the story of the development of these ancient societies. Since the reconstruction procedures employed disregard and in fact destroy any evidence to the contrary, the assumption turns into a perceived fact.

Heterogenetic cities offer many options for creative heritage management in addition to the display of ruins of temples. If Myanmar is to fulfill its tourism potential, it is imperative that extant cultural resources be inventoried, preserved, and interpreted in a sustainable manner.

What would such a program of interpretation include? What aspects of urban life could be recreated, and how should this be done? One can propose several levels of interpretation, from relatively concrete to very speculative, based on different degrees of confidence which one can derive from the archaeological data. For any ancient society, depiction of the forms of daily life will inevitably involve a considerable degree of uncertainty, even for those societies which are well documented in written texts. For ancient Myanmar, and indeed all of Southeast Asia, the textual sources are much sparser than ancient Rome or Chang-an.

When in doubt, archaeologists normally fall back on technology. Here we have our highest degree of certainty, because the primary data of archaeological research yield examples of the finished products of many forms of production, from utilitarian ceramics used in domestic life to the metal statues of the religious sanctuaries. Many techniques, from simple reconstructions of the production process in two-dimensional media, through reconstruction of workshops and even live demonstrations have proven to be popular in many parts of the world. Inscriptions can be used to some extent to amplify the physical record. Archaeological research aimed at discovering production areas such as pottery kilns and metal-working sites could be integrated into the narrative.

The reconstruction of human community life in the past is more difficult, because it must be inferred rather than directly observed from artifacts. It is thus more controversial. There are, however, ways of coping with this uncertainty. One, which is becoming increasingly feasible with the development of information technology, is to provide the viewers/visitors with several alternative reconstructions, and let them choose among them or even manipulate them by making them interactive, so that the viewer/visitor can move between different possible reconstructions, rather than providing a single "authoritative" version.

Urban life in ancient Southeast Asia would have displayed characteristics unique to various parts of the region, and thus would hold intrinsic interest for visitors, could those characteristics be reconstructed. In the maritime regions such as Sumatra, Java, Borneo, the Malay Peninsula, and the Philippines, early European visitors noted some salient characteristics, such as the dense populations found in conjunction with dense foliage (Miksic 1989). Other forms of urban life would range from the kuwu or compounds under the rule of noblemen of fourteenth- 
century Java, to the wooden stockades built by Chinese in Sumatra and described by Marco Polo in 1292:

We disembarked from our ships and for fear of these nasty and brutish folk who kill men for food we dug a big trench round our encampment, extending down to the shore of the harbor at either end. On the embankment of the trench we built five wooden towers or forts; and within these fortifications we lived for five months. (Marco Polo; Latham 1958:254)

In the current state of knowledge of life in ancient Myanmar, very little beyond the nature of the products of art and technology made and used can be reconstructed. All else is hypothetical. All media used to portray the lives of people in any ancient Myanmar sites must therefore carefully avoid giving too much credence to details of life in those sites. On the other hand, the attempt to increase appreciation for and awareness of ancient Myanmar lifeways among both the indigenous people of Myanmar and foreign visitors would have several benefits. On a research level, it would provide direction, and priorities, to the Myanmar archaeological department. On a financial level, it would begin to generate funds from visitors, thus providing evidence that further investment in archaeological research on lifeways, in addition to reconstructions of architectural monuments and other products of artistic endeavor, would in fact be repaid financially. Ideally such evidence should be secondary to the enlightening qualities of the knowledge generated by such research, but in practical terms, archaeologists, who would prefer to spend their time doing what they know best, must be prepared to roll up their sleeves and engage in endeavors to demonstrate that their knowledge can have financial benefits, too.

\section{ACKNOWLEDGMENTS}

Some of the ideas and text contained in this article were presented in a paper entitled "Cities in Ancient Burma: Orthogenetic or Heterogenetic?" at the Myanmar Two Millennia Conference, Yangon, 15-17 December 1999. I am grateful to the Universities Historical Research Commission of Myanmar for permission to use those ideas and portions of that text here.

\section{NOTES}

1. A volume consisting of translations from Vietnamese archaeological articles and contributions by foreign scholars regarding recent studies on Oc-èo culture is expected to be published in Singapore in 2001.

2. The survey was conducted from 1991 to 1993 by the Indonesian Field School of Archaeology with support from the Ford Foundation, the Asian Cultural Council, and the Indonesian National Research Centre for Archaeology. The complete site report has not been published.

\section{REFERENCES CITED}

AdAMS, ROBERT MCC.

1981 Heartland of Cities. Surveys of Ancient Settlement and Land Use on the Central Floodplain of the Euphrates. Chicago and London: University of Chicago Press.

Aung THAW

1968 Report of the Excavations at Beikthano. Rangoon: Ministry of Union Culture, Revolutionary Government of the Union of Burma.

1972 Historical Sites in Burma. Rangoon: Ministry of Union Culture. 
Aung-Thwin, M.

1985 Pagan: The Origins of Modern Burma. Honolulu: University of Hawai'i Press.

Bronson, BENNET, and JAN WisSEMAN

1976 Palembang as Srivijaya: The lateness of early cities in southern Southeast Asia. Asian Perspectives $19(2): 220-239$.

BROWN, R. L.

1996 The Dvaravati Wheels of the Law and the Indianization of South East Asia. Studies in Asian Art and Archaeology, vol. 18, ed. Jan Fontein. Leiden: E. J. Brill.

Christie, Jan W.

1992 Trade and settlement in early Java: Integrating the epigraphic and archaeological data, in Early Metallurgy, Trade and Urban Centers in Thailand and Southeast Asia: 181-197, ed. I. Glover, P. Suchitta, and J. Villers. Bangkok: White Lotus.

1995 State formation in early maritime Southeast Asia: A consideration of the theories and the data. Bijdragen tot de Taal-, Land-en Volkenkunde 151(2) :235-288.

Coe, Michael

1961 Social typology and the tropical forest civilizations. Comparative Studies in Society and History $4(1): 65-85$

Comer, Douglas C.

1994 The SPAFA Unified Cultural Resource Management Guidelines for Southeast Asia, vol. I: Material Culture. Bangkok: SPAFA.

Edwards McKinnon, E.

1984 Kota Cina: Its Context and Meaning in the Trade of Southeast Asia in the Twelfth to Fourteenth Centuries. Ph.D. diss., Cornell University, Ithaca, NY.

FOX, EDWARD WHITING

1971 History in Geographic Perspective: The Other France. New York: W. W. Norton.

FRASCH, T.

1998 King Nadaungmya's great gift, in Études Birmanes en Hommage à Denise Bernot: 27-35, ed. P. Pichard and F. Robinne, Études Thématiques 9. Paris: École Française d'ExtrêmeOrient.

Glover, Ian C.

1989 Early Trade Between India and Southeast Asia: A Link in the Development of a World Trading System. University of Hull, Occasional Paper No. 16. Hull: Centre for Southeast Asian Studies.

Guillot, C., ED.

1998 Histoire de Barus. Le Site de Lobu Tua. I. Études et Documents. Paris: Cahiers d'Archipel 30.

Hall, Kenneth R.

1985 Maritime Trade and State Development in Early Southeast Asia. Honolulu: University of Hawai'i Press.

Higham, Charles

1989 The Archaeology of Mainland Southeast Asia. Cambridge: Cambridge University Press.

I Wayan ARdika, AND P. BellwoOd

1991 Sembiran: The beginnings of Indian contact with Bali. Antiquity 65(247):221-232.

Kijngam, A., C. Higham, and W. Wiriyaromp

1980 Prehistoric Settlement Patterns in North East Thailand. Dunedin: University of Otago Studies in Prehistoric Anthropology 15.

Latham, Martin

1958 The Travels of Marco Polo. Translated and with an introduction by Martin Latham. Harmondsworth: Penguin.

LERTRIT, SAWANG

2000 Cultural resource management and archaeology at Chiang Saen, northern Thailand. Journal of Southeast Asian Studies 31(1): 137-161.

MALleReT, LOUIS

1959- L'archéologie du Delta du Mekong. 4 vols. Paris: Publications de l'École Française

1963 d'Extrême-Orient. 
MANGUin, P.-Y.

1987 Études Sumatranaises I. Palembang et Srivijaya: Anciennes hypotheses, recherches nouvelles. Bulletin de l'École Française d'Extrême-Orient 76:337-402.

Manzanilla, L.

1997 Early Urban Societies: Challenges and Perspectives, in Emergence and Change in Early Urban Societies: 3-42, ed. L. Manzanilla. New York: Plenum Press.

Miksic, John N.

1979 Archaeology, Trade, and Society in Northeast Sumatra. Ph.D. diss., Cornell University, Ithaca, NY.

1989 Urbanization and social change: The case of Sumatra. Archipel 37:1-29.

1991 Settlement patterns and sub-regions in Southeast Asian history. Review of Indonesian and Malaysian Affairs 31(1):86-144.

1994 Survei Permukaan Situs Trowulan 1991 dan Perkotaan di Indonesia pada Zaman Kelasik. Recent research at Trowulan: Implications for early urbanizations in Indonesia. Periemuan Ilmiah Arkeologi 6:357-366. Jakarta: Pusat Penelitian Arkeologi Nasional.

1995a Country report: Singapore. SPAFA workshop on cultural resource management (SW212). National University of Singapore, Republic of Singapore, May 22-27.

$1995 b$ Singapore's material heritage: What has been saved. SPAFA workshop on cultural resource management (SW-212). National University of Singapore, Republic of Singapore, May 22-27.

1998 The theme of the economy in premodern and early modern Indonesian historiography. Paper presented to the 15 th conference of the International Association of Historians of Asia. Jakarta, August 27-September 1.

1999a STB project on thematic linkages between Singapore and selected regional destinations. Product inventory for Myanmar. Unpublished report to the Singapore Tourism Board.

19996 Water, urbanization and disease in early Indonesia, in Complex Polities in the Ancient Tropical World: 167-184, ed. Elizabeth A. Bacus and Lisa J. Lucero, Archaeological Papers of the American Anthropological Association, no. 9. Arlington, VA: American Anthropological Association.

2000 Heterogenetic cities in premodern Southeast Asia. World Archaeology 32(1): 106-120.

MOORE, ELIZABETH

1988 Moated Sites in Early North East Thailand. BAR International Series 400, Oxford.

Mudar, Karen M.

1999 How many Dvaravati kingdoms? Locational analysis of first millennium A.D. moated settlements in central Thailand. Journal of Anthropological Archaeology 18:1-28.

Pichard, Pierre, and F. Robinne

1998 Introduction, in Études Birmanes en Hommage à Denise Bernot: 15-24, ed. P. Pichard and F. Robinne. Études Thématiques 9. Paris: École Française d'Extrême-Orient.

REDField, Robert, and R. Singer

1954 The cultural role of cities. Economic Development and Social Change 3:335-373.

ReID, ANTHONY

1988 Southeast Asia in the Age of Commerce 1450-1680, vol. 1: The Lands belou the Winds. New Haven: Yale.

1993 Southeast Asia in the Age of Commerce 1450-1680, vol. 2: Expansion and Crisis. New Haven: Yale.

Stark, Miriam, P. B. Griffin, C. Phoeurn, J. Ledgerwood, M. Dega, C. Mortland, N. Dowling, J. M. Bayman, B. Sovath, T. Van, C. Chamroeun, K. Latinis

1999 Results of the 1995-1996 archaeological field investigations at Angkor Borei, Cambodia. Asian Perspectives 38(1):7-36.

Vallibhotama, SRisakra

1984 The relevance of moated settlements to the formation of states in Thailand, in Southeast Asian Archaeology at the XV Pacific Science Congress. The Origins of Agriculture, Metallurgy, and the State in Mainland Southeast Asia:123-128, ed. Donn Bayard. Studies in Prehistoric Anthropology Vol. 16. Dunedin: University of Otago.

VICKERY, MiCHAEL

1998 Society, Economics, and Politics in Pre-Angkor Cambodia: The $7^{\text {th }}-8^{\text {th }}$ Centuries. Tokyo: The Centre for East Asian Cultural Studies for UNESCO, The Tokyo Bunko. 
WaLker, M. J., AND S. SANTOSO

1977 Romano-Indian Rouletted Pottery in India. Mankind 11:39-45.

WheATley, Paul

1971 The Pivot of the Four Quarters. Chicago: Aldine.

1975 Satyanrta in Suvarnadvipa: From reciprocity to redistribution in ancient Southeast Asia, in Ancient Trade and Civilization: 227-283, ed. J. A. Sabloff and C. C. Lamberg-Karlovsky. Albuquerque: University of New Mexico.

1983 Nagara and Commandery: Origins of the Southeast Asian Urban Traditions. Department of Geography, Research Papers Nos. 207-208. Chicago: University of Chicago.

WICKS, ROBERT S.

1992 Money, Markets, and Trade in Early Southeast Asia. The Development of Indigenous Monetary Systems to A.D. 1400. Ithaca, NY: Cornell University Southeast Asia Program.

WIENDU NURYANTI, ED.

1993 Universal Tourism: Enriching or Degrading Culture? Yogyakarta: Gadjah Mada University Press.

1997 Tourism and Heritage Management. Yogyakarta: Gadjah Mada University Press.

1999 Heritage, Tourism and Local Communities. Yogyakarta: Gadjah Mada University Press.

WOLTERS, O. W.

1967 Early Indonesian Commerce. London and Ithaca, NY: Cornell University Press.

\begin{abstract}
Urbanization in Southeast Asia is sometimes assumed to have been synonymous with the development of orthogenetic structures such as religious centers under external influence. An alternative hypothesis proposes that social structures stimulated by local cultural and environmental conditions and regional historical events emerged in several parts of Southeast Asia, marked by evolution rather than stasis. One of the major stumbling blocks in the path toward a new theory is a lack of appropriate archaeological data with which to test this hypothesis. A thorough research program is therefore needed to refine and implement a methodology for gathering data on a wide range of characteristics from several sites. Myanmar affords one of the best laboratories for such a program. Restoration projects have seriously affected both structures and distributions of artifacts such as pottery before they were thoroughly studied. Previous research in Thailand and Java can provide models on which planners of a project to investigate ancient urbanization in Myanmar can draw. Sustainable heritage tourism can contribute positively to both archaeological research and public education. KEYWORDS: urbanization, cultural resource management, archaeological survey, Pagan, Majapahit.
\end{abstract}

